\title{
Influence of Malnutrition on the Body Temperature of Children
}

\author{
O. G. BROOKE
}

British Medical fournal, 1972, 1, 331-333

\section{Summary}

The mean auricular temperature of 10 malnourished Jamaican infants was $0.84^{\circ} \mathrm{C}$ lower on admission to hospital than it was after recovery. Body temperature was influenced by ambient temperature in the malnourished state. During the rapid growth that accompanies recovery the mean auricular temperature was raised. Five malnourished children with hypothermia were given a standard high-calorie feed, and this caused the body temperature to return to normal levels within two hours in every case. These results suggest that reduced mean temperature in malnourished children may be an adaptation to conserve calories, and that severe hypothermia in malnutrition results from an acute shortage of energy reserves. Frequent feeding of malnourished children is most important in their management.

\section{Introduction}

Published work on body temperature in infantile malnutrition has been concerned mainly with the occurrence of hypothermia (rectal temperature less than $35^{\circ} \mathrm{C}$ ) and its relation to environmental temperature, severity of malnutrition, and prognosis (Kahn, 1959; Morley, 1960; Brenton et al., 1967; Staff, 1968). Hypothermia in malnourished infants has been reported from several tropical areas (Morley, 1960; Lawless and Lawless, 1963; Brenton et al., 1967). It is also found in Jamaica. The climate in Kingston, where the present studies took place, is warm, humid, and lacking in large diurnal variation. The mean monthly temperature is lowest in February $\left(24.2^{\circ} \mathrm{C}\right)$ and highest in July $\left(27 \cdot 2^{\circ} \mathrm{C}\right)$. The average daily minimum temperature is $17 \cdot 7^{\circ} \mathrm{C}$ for February and $21.3^{\circ} \mathrm{C}$ for July. ${ }^{*}$ In spite of the warm

\footnotetext{
- Figures from Jamaica Government Meteorological Report No. 862 for
} years 1943-1949. Tropical Metabolism Research Unit, University of the West Indies,

O. G. BROOKE, M.B., M.R.C.P., M.R.C. External Staff Member climate, hypothermia is regularly seen in Jamaican children with protein-calorie malnutrition, and in a recently reviewed series of 137 consecutive admissions to this unit, $20 \%$ had a rectal temperature of $35^{\circ} \mathrm{C}\left(95^{\circ} \mathrm{F}\right)$ or less at some time during their first week in hospital.

The studies reported here are the first of a series designed to investigate thermoregulation in malnourished infants. Mean central body temperature was measured in 10 malnourished children, on admission to the ward and during recovery. None of these children became hypothermic (core temperature less than $35^{\circ} \mathrm{C}$ ) during the studies. In addition, some results are reported of investigations performed on five hypothermic infants during the course of other metabolic studies.

\section{Patients and Methods}

Some clinical details of the two groups of patients are given in Tables I and II. One child (Case 11) had kernicterus resulting

\begin{tabular}{|c|c|c|c|c|c|c|c|}
\hline \multirow{2}{*}{$\begin{array}{l}\text { Case } \\
\text { No. }\end{array}$} & \multirow[b]{2}{*}{ Sex } & \multirow{2}{*}{$\begin{array}{c}\text { Age on } \\
\text { Admission } \\
\text { (Months) }\end{array}$} & \multicolumn{2}{|c|}{ Weight (kg) } & \multicolumn{2}{|c|}{ Height (cm) } & \multirow[b]{2}{*}{ Oedema } \\
\hline & & & $\begin{array}{c}\text { On } \\
\text { Admission }\end{array}$ & $\begin{array}{c}\text { After } \\
\text { Recovery }\end{array}$ & $\begin{array}{c}\text { On } \\
\text { Admission }\end{array}$ & $\begin{array}{c}\text { After } \\
\text { Recovery }\end{array}$ & \\
\hline $\begin{array}{r}1 \\
2 \\
3 \\
4 \\
5 \\
6 \\
7 \\
8 \\
9 \\
10\end{array}$ & $\begin{array}{l}\text { M. } \\
\text { M. } \\
\text { F. } \\
\text { M. } \\
\text { F. } \\
\text { M. } \\
\text { M. } \\
\text { M. } \\
\text { F. } \\
\text { M. }\end{array}$ & $\begin{array}{r}11 \\
9 \\
11 \\
19 \\
18 \\
7 \\
12 \\
17 \\
16 \\
10\end{array}$ & $\begin{array}{l}5 \cdot 9 \\
5 \cdot 2 \\
3 \cdot 8 \\
5 \cdot 3 \\
6.7 \\
5.9 \\
5.7 \\
7.4 \\
7.5 \\
5.3\end{array}$ & $\begin{array}{r}8.3 \\
7.6 \\
6.9 \\
9.9 \\
9.4 \\
7.9 \\
8.9 \\
10.5 \\
10.1 \\
7.0\end{array}$ & $\begin{array}{l}66 \cdot 0 \\
64 \cdot 0 \\
57 \cdot 0 \\
63 \cdot 5 \\
70 \cdot 0 \\
63 \cdot 0 \\
68.5 \\
72.5 \\
66.0 \\
71 \cdot 0\end{array}$ & $\begin{array}{l}68 \cdot 0 \\
65 \cdot 5 \\
60 \cdot 0 \\
66 \cdot 5 \\
72 \cdot 0 \\
66 \cdot 0 \\
70 \cdot 0 \\
74 \cdot 5 \\
68 \cdot 0 \\
72 \cdot 5\end{array}$ & $\begin{array}{l}+ \\
0 \\
0 \\
0 \\
0 \\
0 \\
0 \\
0 \\
+ \\
0\end{array}$ \\
\hline \multicolumn{2}{|c|}{ Mean } & 13 & $5 \cdot 9$ & $8 \cdot 6$ & $66 \cdot 1$ & $68 \cdot 3$ & \\
\hline
\end{tabular}

TABLE II-Five Malnourished Famaican Children who became Hypothermic after Admission

\begin{tabular}{c|c|c|c|c|c}
\hline $\begin{array}{c}\text { Case } \\
\text { No. }\end{array}$ & Sex & $\begin{array}{c}\text { Age on } \\
\text { Admission } \\
\text { (Months) }\end{array}$ & $\begin{array}{c}\text { Weight (kg) } \\
\text { on Admission }\end{array}$ & $\begin{array}{c}\text { Height (cm) } \\
\text { on Admission }\end{array}$ & Oedema \\
\hline 11 & M. & 12 & $3 \cdot 6$ & $58 \cdot 5$ & 0 \\
12 & F. & 14 & $5 \cdot 0$ & $67 \cdot 0$ & + \\
13 & M. & 10 & $8 \cdot 1$ & 62.5 & 0 \\
15 & M. & 18 & $4 \cdot 1$ & $65 \cdot 0$ & 0 \\
\hline & Mean & $12 \cdot 4$ & 4.9 & $69 \cdot 0$ & + \\
\hline
\end{tabular}


from rhesus incompatibility, but had been admitted on account of severe nutritional marasmus. Core temperature was measured to an accuracy of $\pm 0.05^{\circ} \mathrm{C}$ with a thermistor probe in the external auditory meatuses of 10 malnourished children (Table I), selected only in that they had no fever or evidence of infection. Measurements were made during three 48-hour periodson admission, during the phase of rapid recovery growth, and after recovery - and were recorded on a chart recorder. Ambient temperature was recorded simultaneously. Temperature means were derived from 96 readings from each 48-hour period (halfhour intervals).

A test meal (at $30^{\circ} \mathrm{C}$ or less), which provided $27 \mathrm{kcal}$ and $0.7 \mathrm{~g}$ of milk protein per $\mathrm{kg}$ body weight, was given through a nasogastric tube to these 10 children shortly after their admission, and also to the five hypothermic malnourished babies (Table II). The feed was given four hours after the previous meal except in two children (Cases 11 and 15) who were fasted for eight hours. In all the children a continuous record was made of rectal temperature, measured to an accuracy of $\pm 0.5^{\circ} \mathrm{C}$ with a thermistor probe inserted $5 \mathrm{~cm}$ into the rectum. Four of the hypothermic babies and all 10 of those without hypothermia were studied in a metabolic chamber in which the environmental temperature could be controlled accurately. Oxygen consumption and $\mathrm{CO}_{2}$ evolution were measured with a Kipp and Zonen Noyons diaferometer, both before the feed and afterwards at 15-minute intervals for two hours. One child (Case 15) was found to be hypoglycaemic before the test and was given intravenous glucose in addition to the test meal.

\section{Results}

\section{MEAN TEMPERATURES OF 10 MALNOURISHED CHILDREN}

The mean temperatures of the 10 malnourished children during the three measurement periods are shown in Fig. 1, together with their standard deviations. On recovery the mean auricular temperature was $0.84^{\circ} \mathrm{C}$ higher than it was on admission, and the difference is highly significant $(t=7 \cdot 7, \mathrm{P}<0.001)$. During rapid growth the mean temperature was $0 \cdot 14^{\circ} \mathrm{C}$ higher than it was after recovery. This difference, though small, was also significant $(t=2 \cdot 9, \mathrm{P}<0.05)$.

The children's temperatures showed greater variability on admission than they did after recovery. The mean sample variance of the temperature readings on admission was $0.202^{\circ} \mathrm{C}$, while after recovery it was $0.048^{\circ} \mathrm{C}$. This was partly due to the profound effect of sleep on body temperature in the malnourished state. Fig. 2 shows a one-and-a-half-hour period of sleep accompanied by a fall of $1.4^{\circ} \mathrm{C}$ in auricular temperature. Changes of this magnitude did not occur after recovery. Fig. 3 shows that there was a tendency for the body temperatures of the malnourished children to follow the ambient temperature in the ward. The latter varied between 25.5 and $32.2^{\circ} \mathrm{C}$ during the months in which the studies took place, being highest at about

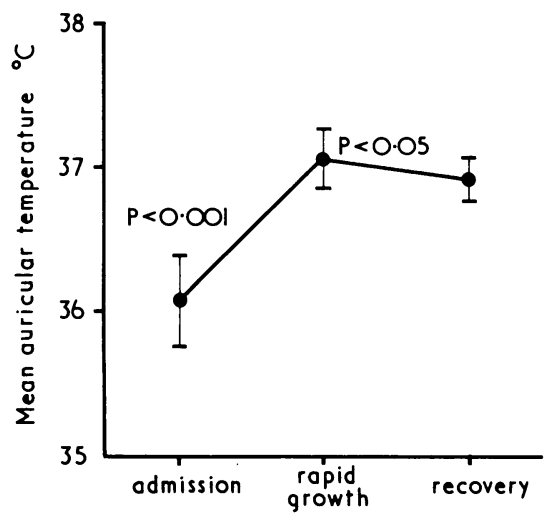

FIG. 1-Mean auricular temperature of 10 malnourished infants during three 48-hour measurement periods, with standard deviations.

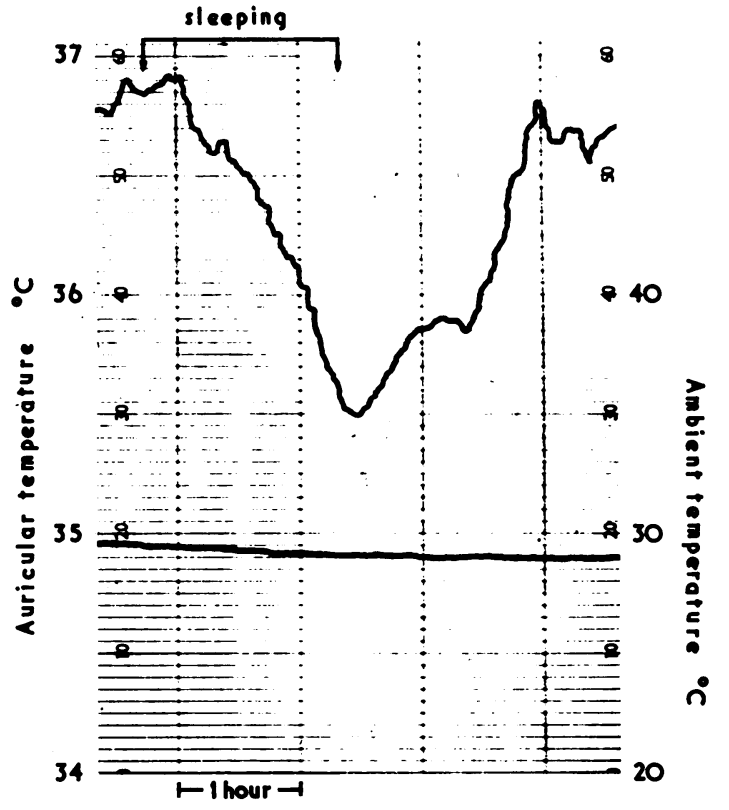

FIG. 2-A one-and-a-half-hour period of sleep in Case 4, showing pronounced fall in auricular temperature.

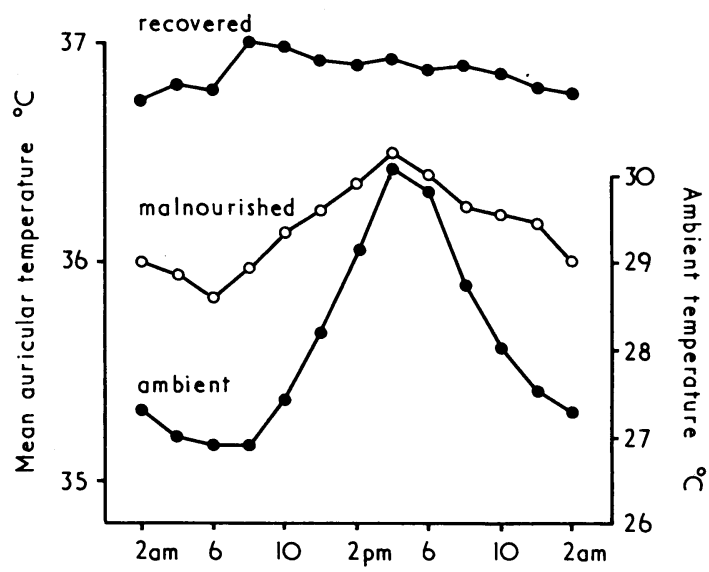

FIG. 3-Mean auricular temperature of 10 malnourished FIG. 3-Mean auricular temperature of 10 malnourished to mean ambient temperature during 24 hours.

4.30 p.m. and lowest between 6 and 8 a.m. The auricular temperature of the malnourished children reached its highest point $\left(36.52^{\circ} \mathrm{C}\right)$ at 5 p.m. and was lowest at about 6.30 a.m. $\left(35 \cdot 83^{\circ} \mathrm{C}\right)$. In contrast, when the children had recovered their mean temperature was highest at about 9.30 a.m. and lowest at 1 a.m. The maximum and minimum ambient temperatures which each patient experienced during the course of his stay in hospital did not vary by more than $1.3^{\circ} \mathrm{C}$.

When these 10 children were given the standard test meal shortly after their admission the mean rise in rectal temperature was $0.11^{\circ} \mathrm{C}$ at one hour. This was not significant, neither was an increase in metabolic rate of $4 \%$ at one hour.

\section{HYPOTHERMIC PATIENTS}

These five children all had a rectal temperature of $35 \cdot 10^{\circ} \mathrm{C}$ or less at the time of the study. During a 30 -minute period of observation in a thermoneutral environment the mean temperature of the group fell by $0.13^{\circ} \mathrm{C}$, and at the time of administration of the test meal it was $34 \cdot 82^{\circ} \mathrm{C}$ (S.D. $0 \cdot 15^{\circ} \mathrm{C}$ ). The effect of the test meal on rectal temperature (five patients) and metabolic rate (four patients) is shown in Fig. 4. By two hours after the meal, with no external aids to rewarming, rectal temperatures had reached a mean of $36.62^{\circ} \mathrm{C}$, which is within the normal range, while metabolic rate had increased by $31 \%$. 


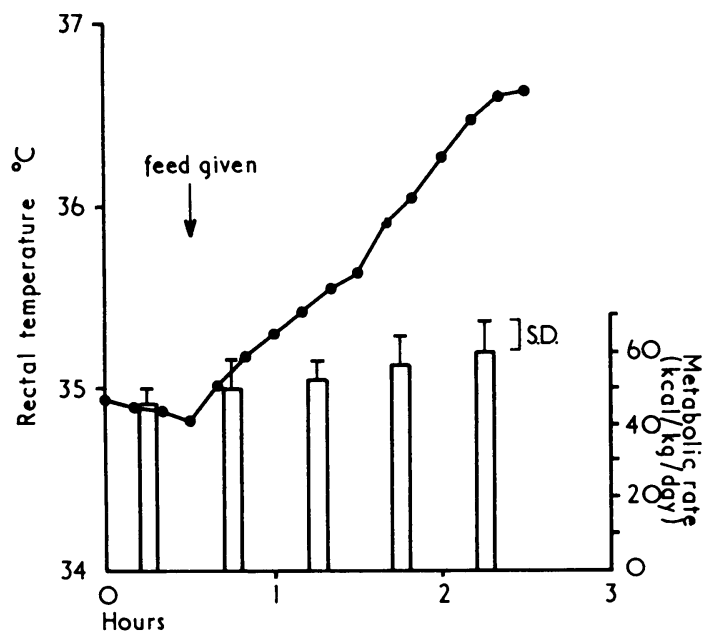

FIG. 4-Effect of high-calorie feed on rectal temperature (five patients) and metabolic rate (four patients) of hypothermic malnourished children.

The increases in temperature and metabolic rate were both significant $(t=6.30, \mathrm{P}<0.01$ and $t=20.2, \mathrm{P}<0.001$ respectively for metabolic rate and rectal temperature increase two hours after the meal). One patient (Case 11) was later found to have been hypoglycaemic at the start of the study, with a blood sugar of $17.5 \mathrm{mg} / 100 \mathrm{ml}$, though he was asymptomatic except for his hypothermic state. Another child (Case 15) was tested for hypoglycaemia when he became hypothermic, and blood glucose, estimated by Dextrostix, was less than $45 \mathrm{mg} / 100 \mathrm{ml}$. However, he had been given $3 \mathrm{~g}$ of dextrose orally 30 minutes earlier and a blood glucose estimation, performed 15 minutes after the Dextrostix test, did not confirm hypoglycaemia.

\section{Disc ussion}

Reduction in body temperature has been observed on many occasions in fasted or undernourished adults and in animals. The subject has been well documented by McCance and Mount (1960). It is clear from the results reported here that malnourished children are no exception, for not only are they liable to episodes of hypothermia but, in addition, their mean temperatures are significantly reduced. A rise in mean body temperature during the growth phase of recovery has not previously been described. It is attributable to the postprandial heat production which accompanies a tenfold increase in growth rate, and which is believed to reflect the energy cost of tissue synthesis (Brooke and Ashworth, 1972).

Several explanations might be advanced to account for the finding of lowered body temperature in malnutrition. Three important possibilities are: (1) a deficiency of energy reserves, with consequent reduction in overall metabolism; (2) defective thermoregulatory function in heat-losing environments; and (3) an adaptation to low calorie intake, to allow a reduction in calorie expenditure. It is likely that the first factor was dominant in the five hypothermic infants. One of these was definitely hypoglycaemic and one probably so, indicating exhaustion of glycogen reserves and failure of gluconeogenesis. Four of these children had low metabolic rates (not measured in Case 15), ranging from 39.7 to $51.7 \mathrm{kcal} / \mathrm{kg} /$ day. The mean of $46 \cdot 2 \mathrm{kcal} / \mathrm{kg} /$ day is $33 \%$ lower than the mean value previously found for 15 newly admitted normothermic malnourished children studied after a four-hour fast. The rise in metabolic rate and body temperature after the provision of food is dramatic.

Emphasis has previously been laid on the physical rewarming of hypothermic malnourished children (Morley, 1960; Brenton et al., 1967) but it seems that food will serve the purpose just as well, and the importance of frequent feeding cannot be overemphasized. However, in view of the pronounced fall in body temperature which occurs in the sleeping malnourished child, it is important to provide covering at night, especially in climates with low nocturnal temperatures. A further point of clinical importance is the occurrence of otherwise asymptomatic hypoglycaemia in at least one case, and probably in two cases. The association between hypothermia and hypoglycaemia has been reported from Hungary (Kerpel-Fronius et al., 1954) and from Uganda (Wharton, 1970), where it is usually associated with infection and has a poor prognosis. Though Case 15 subsequently developed a respiratory tract infection, neither of these children died. It is emphasized that hypothermia alone may be an important clinical sign of hypoglycaemia in some malnourished children.

None of the group of 10 children in whom mean auricular temperature was monitored became hypothermic. Since these children did not respond to a test meal with a rise in temperature or metabolic rate, it is unlikely that acute shortage of energy sources was responsible for their lowered body temperature.

Impaired thermoregulatory efficiency may play a part in the reduction of body temperature in malnourished children. Tissue insulation is certainly reduced, since loss of subcutaneous fat is a prominent feature in many of our cases. At necropsy brown adipose tissue appears scanty compared with that found in normally nourished Jamaican children of this age group, and histological examination of the tissue often shows fat depletion (M. Harris and O. G. Brooke, unpublished data). The tendency for the malnourished child's temperature to follow the ambient temperature also indicates impairment of thermoregulation. Published data on the metabolic response to cold in malnourished infants are scanty, but Kerpel-Fronius et al. (1954) showed that marasmic infants who were hypothermic had lower rates of oxygen consumption than those who had normal temperatures. However, these children are still capable of developing fever. In a review of 137 cases of malnutrition consecutively admitted to this unit, 39 had rectal temperatures of $37.8^{\circ} \mathrm{C}$ or higher at some stage during the first week of admission, and eight of these had a temperature of $35^{\circ} \mathrm{C}$ or less during the same period. Swings of temperature ranging from 35 to $39.4^{\circ} \mathrm{C}$ have been observed within one 12 -hour period, showing that the ability to raise body temperature is retained to great effect.

The lowered mean temperature reported here may represent an adaptation to conserve calories. The association between low metabolic rate and reduced body temperature has been described (Barnes, 1942), and it is well established that in prolonged starvation adults have lowered basal metabolic rates (Keys et al., 1950). In malnourished children the situation is far from clear, and the reasons for this have been discussed by Ashworth $(1969,1970)$. The finding of reduced body temperature in these 10 children suggests that the overall metabolic rate is in fact reduced. I propose that the primary event may be a readjustment of the hypothalmic thermostat to a lower level. This would allow a reduction in metabolic rate and hence a saving in calorie expenditure. Thermal instability resulting from impaired thermoregulatory capacity is superimposed on this picture. During periods of acute shortage of energy reserves the development of hypothermia may be an attempt by the organism to alleviate the effects of hypoglycaemia by reducing energy requirements still further.

\section{References}

Ashworth, A. (1969). Nature, 223, 407.

Ashworth, A. (1970). Nutrition Reviews, 28, 279

Barnes, B (1942). Fournal of the American Medical Association, 119, 1072. Brenton, D. P., Brown, R. E., and Wharton, B. A. (1967). Lancet, 1, 410. Brooke, O. G., and Ashworth, A. (1972). British fournal of Nutrition. In press.

Kahn, E. (1959). American fournal of Clinical Nutrition, 7, 161.

Kerpel-Fronius, von E., Varga, F., and Kun, K. (1954). Annales Paediatrici, $183,1$.

Keys, A., Brozek, J., Henschel, A., Mickelsen, O., and Taylor, H. L. (1950). The Biology of Human Starvation. Minneapolis, University of Minnesota Press.

Lawless, J., and Lawless, M. M. (1963). Lancet, 2, 972.

McCance, R. A., and Mount, L. E. (1960). British fournal of Nutrition, 14,

Mo9. R. A., and Mount, L. E. (1960
Morley, D. C. (1960). Lancet, 2, 1170.

Staff, T. H. E. (1968). East African Medical fournal, 45, 399.

Wharton, B. (1970). Lancet, 1, 171. 